\title{
Design, synthesis and photochemical properties of the first examples of iminosugar clusters based on fluorescent cores
}

\author{
Mathieu L. Lepage ${ }^{1}$, Antoine Mirloup ${ }^{2}$, Manon Ripoll ${ }^{1}$, Fabien Stauffert ${ }^{1}$, \\ Anne Bodlenner ${ }^{1}$, Raymond Ziessel ${ }^{* 2}$ and Philippe Compain ${ }^{* 1,3}$
}

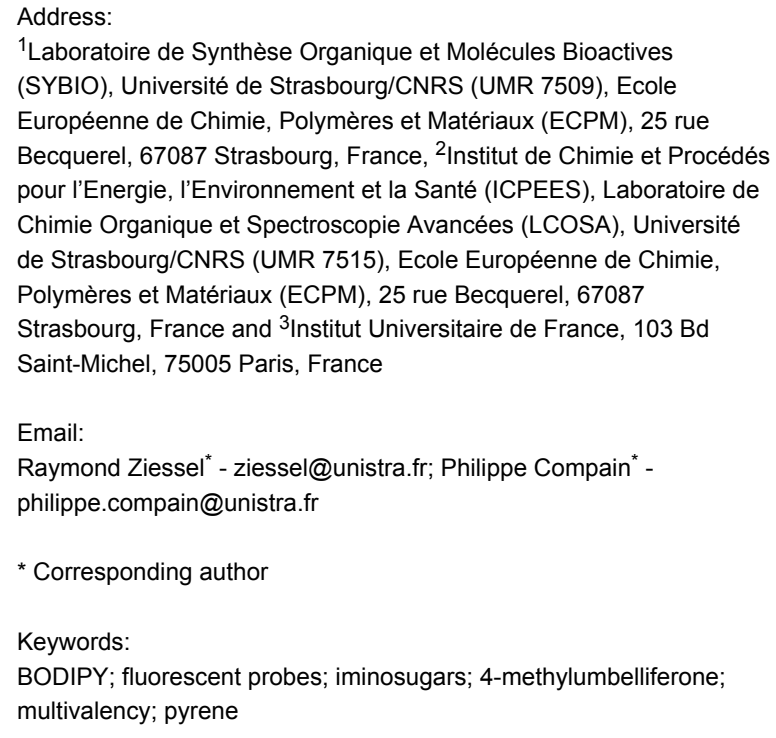

\begin{abstract}
Beilstein J. Org. Chem. 2015, 11, 659-667.
\end{abstract}
doi:10.3762/bjoc. 11.74

Received: 27 February 2015

Accepted: 17 April 2015

Published: 06 May 2015

This article is part of the Thematic Series "Multivalency as a chemical organization and action principle".

Guest Editor: R. Haag

(C) 2015 Lepage et al; licensee Beilstein-Institut. License and terms: see end of document.

\begin{abstract}
The synthesis and photophysical properties of the first examples of iminosugar clusters based on a BODIPY or a pyrene core are reported. The tri- and tetravalent systems designed as molecular probes and synthesized by way of $\mathrm{Cu}(\mathrm{I})$-catalysed azide-alkyne cycloadditions are fluorescent analogues of potent pharmacological chaperones/correctors recently reported in the field of Gaucher disease and cystic fibrosis, two rare genetic diseases caused by protein misfolding.
\end{abstract}

\section{Introduction}

Since the isolation in the 1970's of 1-deoxynojirimycin (DNJ) from natural sources and the finding of its biological activity as an $\alpha$-glucosidase inhibitor, thousands of sugar mimetics with a nitrogen atom replacing the endocyclic oxygen have been reported in the literature $[1,2]$. Iminosugars are mainly known to be inhibitors of a number of carbohydrate-processing enzymes with an emphasis on glycosidases $[1,2]$. In the early 2000's, iminosugars were, remarkably, found to inhibit metallo- proteinases [3], protein kinases [4] and cholinesterases [5], which are enzymes that act on non-sugar substrates. The versatility of iminosugars as inhibitors of enzymes of therapeutic interest has been harnessed to cure a diversity of diseases including diabetes, viral infection, lysosomal storage disorders, tumour metastasis and cystic fibrosis [1]. First therapeutic successes have been obtained as demonstrated by the number of structures involved in clinical trials and two medicines on the 
market: Glyset ( $N$-hydroxyethyl DNJ) for the treatment of complications associated with type II diabetes and Zavesca $(N-\mathrm{Bu} \mathrm{DNJ}, 1)$, the first oral treatment for Gaucher and Niemann-Pick diseases (Figure 1) [1,6-8]. Despite their high therapeutic potential, the extensive studies in the field and the myriad of compounds synthesized, very few examples of multivalent iminosugars were reported in the literature until recently $[9,10]$. From 2010, the field has however experienced a major take-off with the discovery of the first strong multivalent effects in glycosidase inhibition observed with DNJ clusters based on $\beta$-cyclodextrin or $\mathrm{C}_{60}$ cores showing strong affinity enhancements over the corresponding monomers (up to 610-fold per DNJ unit) $[11,12]$. In the following years, an impressive evergrowing number of multivalent iminosugars based on various scaffolds, ligands and linkers have been synthesized to further investigate the impact of multivalency on glycosidase inhibition [9-26]. The interest of the inhibitory multivalent effect for drug discovery was demonstrated by targeting glycosidases involved in rare genetic diseases linked to misfolded proteins [24-26]. The first examples of multivalent iminosugars such as $\mathbf{2}$ and $\mathbf{3}$ acting as pharmacological chaperones were thus disclosed in the field of Gaucher disease, the most common lysosomal storage disorder (Figure 1) [24,25]. DNJ clusters 2 and $\mathbf{3}$ are indeed able to increase mutant $\beta$-glucocerebrosidase (GCase) residual activity levels as much as 3.3-fold in cells of Gaucher patients at micromolar concentrations. In another rare genetic disease, the rescue by multimeric correctors of the mutant CFTR protein implied in cystic fibrosis led to the first report of a multivalent effect for amending protein folding defects in cells [26]. As judged by $\mathrm{EC}_{50}$ (half-maximal effective concentration) values, trivalent DNJ clusters 2 were indeed up to 225-fold more efficient as CFTR correctors than the clinical candidate $N$-Bu DNJ (1), a potent inhibitor of trimming ER glucosidases [26]. Taken together, these recent studies provide new therapeutic answers for a number of protein folding disorders [27,28] but also raise many fundamental questions concerning the mechanisms at play. In the present paper, we report the first examples of fluorescently-labeled multivalent iminosugars designed as molecular tools to investigate the mode of action of pharmacological chaperones/correctors in cells and in vivo, and get insights into the multivalent effect observed in CFTR correcting activity. The originality of our approach relies on the fact that, in the structures designed, this is the scaffold itself $[29,30]$, based on a pyrene or a boron-dipyrromethene (F-BODIPY) dye, which has fluorescence activity.

\section{Results and Discussion Synthetic design}

The fluorescent probes were designed as analogues of the best multivalent pharmacological chaperones/correctors reported so far that typically display three to four copies of a DNJ ligand

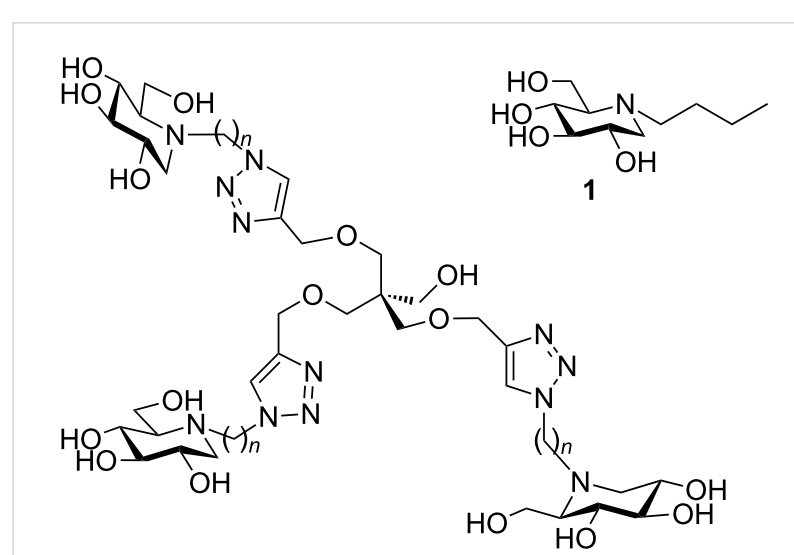

2a: $n=6 ; 2 \mathbf{b}: n=9$

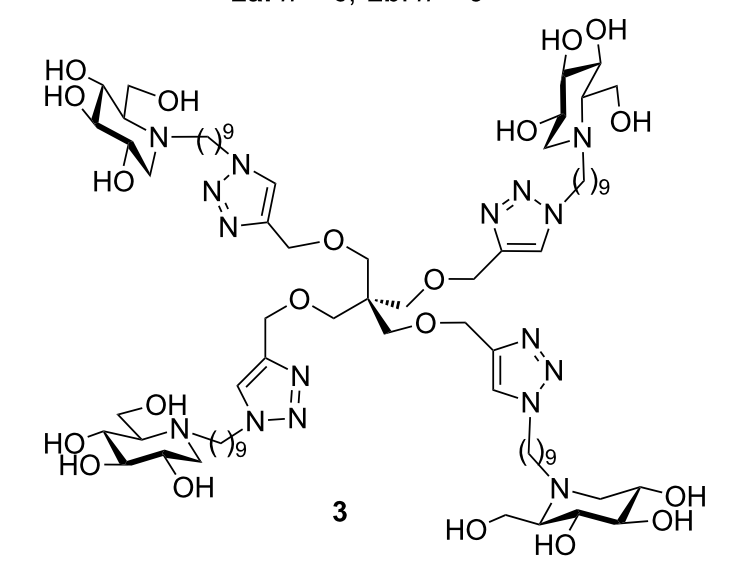

Figure 1: N-Bu DNJ (1) and examples of potent multivalent pharmacological chaperones and CFTR correctors (2 and $\mathbf{3})$.

linked to a central core via an alkyl chain spacer (Figure 1) [2426]. The choice of the fluorophore core is naturally primordial for the design of photostable, water-soluble and biocompatible probes with the required photophysical properties. An additional challenge is that, as the central core of a multivalent system, the fluorophore structure defines also its valency, size and shape. Difluoroboradiaza- $s$-indacenes, commonly named borondipyrromethene dyes (F-BODIPY), were logically selected for the construction of the probes. These compounds indeed combine high fluorescence quantum yields and high molar extinction coefficients, strong chemical and photochemical stability in solution and in solid state. In addition, they can be easily derivatized [31-37]. If the optical properties of BODIPY are very sensitive to modification of the pyrrole core [38,39], they are less sensitive to the substitution of the central pseudo meso position [40,41]. Additionally, the fluorine substitution at the boron has less influence on the spectroscopic properties of the dyes [42]. So far, major endeavors have been dedicated to the preparation of classical F-BODIPY structures and less common E-BODIPY (E for ethynyl) and the examination of their spectroscopic and salient physical properties [43-47]. We have recently argued the case that the fluoro-substitution of 
boraindacene was a mean to considerably increase the solubility, the stability and the steric hindrance avoiding the formation of aggregates [48]. In some cases, special sensing properties [49] may be induced by adequate tailoring, including fluorescence amplification [50], and ratiometric $\mathrm{pH}$ reporter for imaging protein-dye conjugates in living cells [51], or display physiological binding of D-glucose [52]. The pyrene nucleus was also selected as an alternative fluorophore since it may be easily tetrafunctionalized at the $1,3,6$ and 8 positions to give a suitable core for the synthesis of tetravalent clusters [53]. In addition, this fluorophore was chosen for its biological/chemical stability and its photophysical properties including high extinction coefficient with reliable fluorescence [54,55]. Another interest of the pyrene scaffold lies in its rigidity, a property that may favourably impact inhibitory multivalent effects $[9,11,16,19]$. A convergent approach comprising the attachment of azide-armed iminosugars 4 [11,12] on polyalkyne "clickable" scaffolds 5 and $\mathbf{6}$ via $\mathrm{Cu}(\mathrm{I})$-catalyzed azide-alkyne cycloaddition (CuAAC) was performed for achieving our synthetic goals (Figure 2) [56,57]. With the objective of increasing water solubility and chemical stability in biological medium, triyne $\mathbf{6 b}$, an analogue of F-BODIPY-based scaffold $\mathbf{6 a}$ was prepared by replacing the fluoro groups on the boron center with ethynyl tetra(ethylene glycol)methyl groups [58,59].

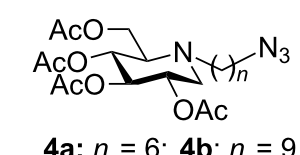

4a: $n=6 ; 4 b: n=9$

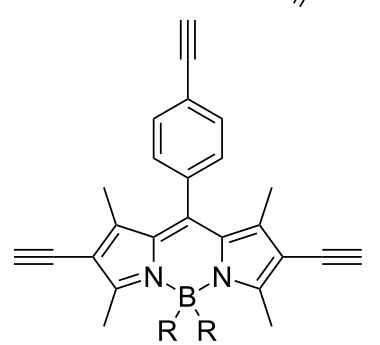

6a: $\mathrm{R}=\mathrm{F} ; \mathbf{6 b}: \mathrm{R}=-\left\{-\mathrm{C} \equiv \mathrm{C}-\mathrm{CH}_{2}\left(\mathrm{OCH}_{2} \mathrm{CH}_{2}\right)_{4} \mathrm{OMe}\right.$

Figure 2: Azide-armed DNJ derivatives 4 and polyalkyne "clickable" scaffolds 5 and $\mathbf{6}$.

\section{Synthesis of the BODIPY precursors}

The synthesis of the tris-iodo functionalized BODIPY dyes and their acetylenic derivatives is sketched in Scheme 1. The synthesis of derivatives $\mathbf{7}$ and $\mathbf{8}$ have previously been reported using a regioselective iodination reaction positions 2 and 6 of the BODIPY [60]. Substitution of both fluoro groups on the boron was realized using the Grignard reagent of 1-[2"'-(2"- \{2'-(2-methoxyethoxy)ethoxy\} ethoxy)ethoxy]prop-2-yne [61] and the BODIPY derivative 8 . With these precursors in hands it was easy to transform the iodo function to yield the trimethylsilylacetylene derivatives $\mathbf{9}$ and $\mathbf{1 1}$ using standard Sonogashira-Hagihira cross-coupling reactions promoted by low valent palladium precursors [62]. Excellent yields were obtained for the trisubstituted derivatives ( 88 to $95 \%$ ). Two diagnostic NMR signals of the poly(ethylene glycol) chains at $4.16 \mathrm{ppm}$ (protons a, integration $4 \mathrm{H}$ ) and at $3.65 \mathrm{ppm}$ for the methoxy groups (protons $\mathrm{b}$, integration $6 \mathrm{H}$ ) in addition to the presence of two TMS singlets at 0.20 and $0.28 \mathrm{ppm}$ (respective integration 18 and $9 \mathrm{H}$ ) confirmed the substitution. Finally, deprotection of the trimethylsilyl group using mild basic conditions provided the target compounds $\mathbf{6 a}$ and $\mathbf{6 b}$ in good yields. Terminal alkynes located in the 2,6 positions were found to resonate at $3.32 \mathrm{ppm}$ and the one in the pseudo meso position 8 resonates at $3.20 \mathrm{ppm}$.

\section{Fluorescent DNJ cluster synthesis}

Following a robust strategy developed in our group [11,12], the last stages of the multivalent probe synthesis involved the attachment of peracetylated azido iminosugars 4 on the scaffolds via $\mathrm{CuAAC}$ reaction and afterwards $O$-deacetylation using an anion exchange resin. First attempts to perform CuAAC reactions with triyne substrate $\mathbf{6 b}$ bearing a tetraethylene glycol chain tethered to the boron center via an ethynyl bond proved difficult. The use of copper(I) bromide dimethyl sulfide complex [63] at room temperature led to a complex mixture of products. Better results were obtained with copper(II) sulfate and sodium ascorbate under carefully degassed conditions and the desired protected cluster $12 \mathrm{~b}$ could be obtained in $56 \%$ yield after purification on silica gel (Scheme 2). The major side-product observed which could not be isolated in pure form may correspond to $\mathrm{CuAAC}$ reaction of the azido iminosugar $4 \mathbf{a}$ with the terminal alkyne resulting from the cleavage of the carbon-boron bond in $\mathbf{6 b}$. The same experimental protocol was applied to functionalized BODIPY $\mathbf{6 a}$, leading to the desired trivalent cluster 12a in $83 \%$ yield. $O$-Deacetylation of compounds 12 using anion exchange Amberlite IRA-400 ( $\left.\mathrm{OH}^{-}\right)$ resin provided the desired water-soluble clusters 13 in high yields. As judged by ${ }^{11} \mathrm{~B}$ NMR, no fluoride displacement occurred at the boron center during the deprotection step.

The synthesis of the 4-valent pyrene-based iminosugars 15 was performed in a similar manner than for BODIPY-based clusters 13 (Scheme 3). The tetrayne 5 synthesized in 3 steps from pyrene [53] was reacted with the azide precursors 4 , and afterwards deprotected to give the desired tetravalent iminosugars 15 in 37 to $72 \%$ yields for the two steps. Despite the good water solubility of alkylated DNJ ligands, pyrene-based multivalent iminosugars were only soluble in water/methanol or water/ 


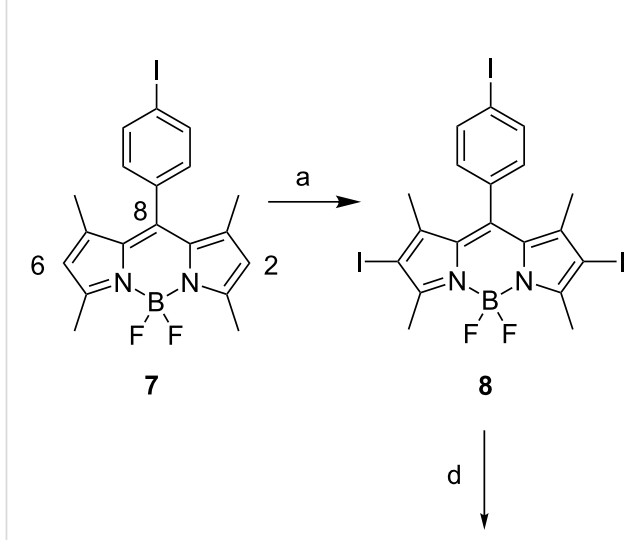

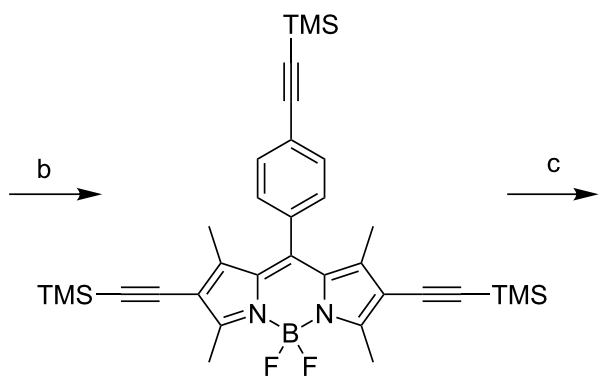

9<smiles></smiles>

$6 a$

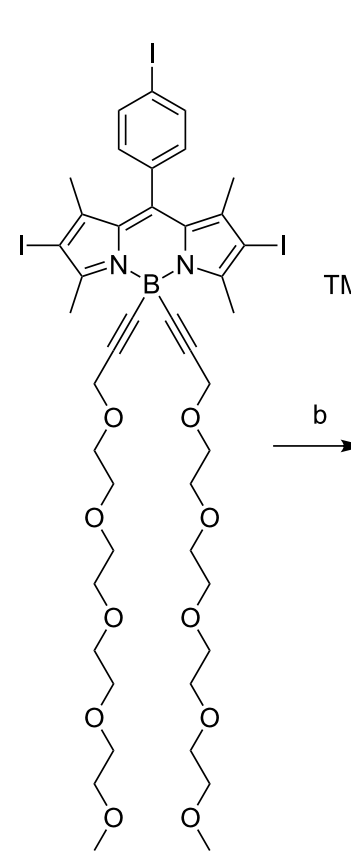

10

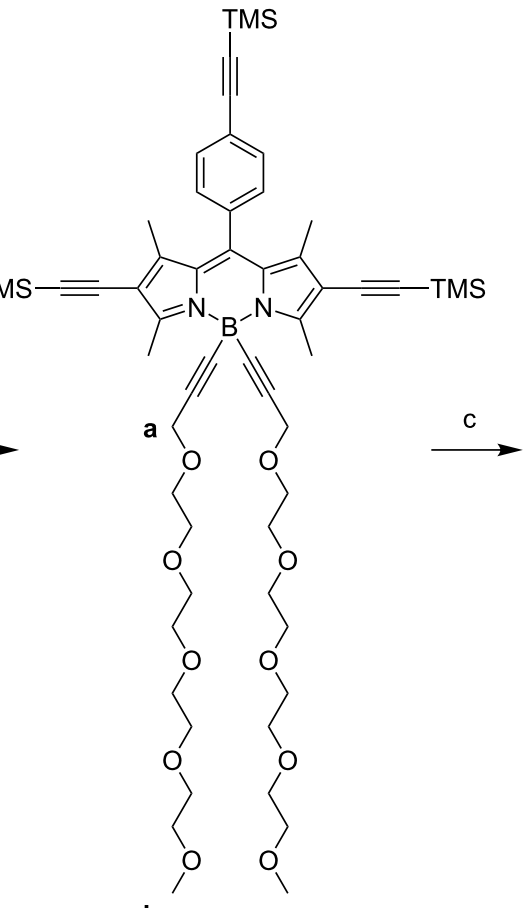

b

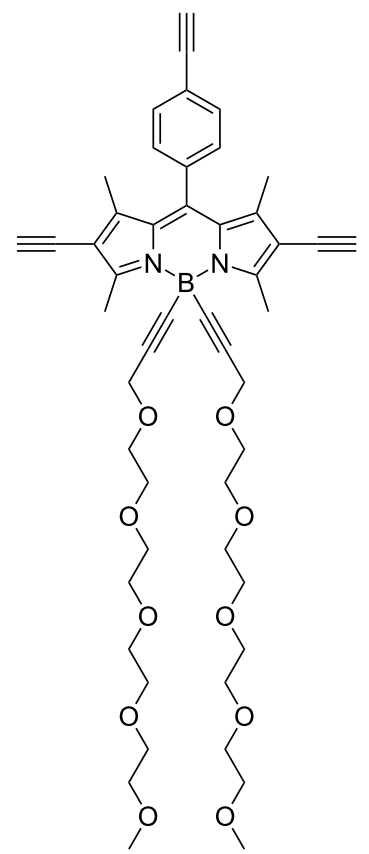

6b

Scheme 1: Synthesis of trisubstituted BODIPY derivatives. (a) ICl, $\mathrm{CHCl}_{3} / \mathrm{MeOH}, \mathrm{rt}, 15 \mathrm{~min}$, quantitative; (b) 3-ethynyltrimethylsilane, $\left[\mathrm{Pd}\left(\mathrm{PPh}_{3}\right)_{2} \mathrm{Cl}_{2}\right]$, Cul, triethylamine, THF, $16 \mathrm{~h}, 60^{\circ} \mathrm{C}, 88 \%$ (9), $95 \%$ (11); (c) $\mathrm{K}_{2} \mathrm{CO}_{3}$, DCM/MeOH/water, $50{ }^{\circ} \mathrm{C}, 16 \mathrm{~h}, 72 \%$ (6a), 88\% (6b); (d) 1-[2"'-(2"-\{2'-(2methoxyethoxy)ethoxy\}ethoxy)ethoxy]prop-2-yne, EtMgBr, THF, $60{ }^{\circ} \mathrm{C}, 16 \mathrm{~h}, 61 \%$.

DMSO mixtures, those mixtures prevent the agregation of the pyrene core.

\section{Photophysical properties}

The absorption and emission features of the BODIPY-based cluster 13a and the pyrene-based cluster 15a dyes were investigated in an aqueous buffer solution of glycine $(0.1 \mathrm{M})$ at $\mathrm{pH}$ 10.7. This buffer conditions were chosen to be as close as possible to the conditions used for $\beta$-glucocerebrosidase activation assays (Gaucher disease) which are based on a fluorescent leaving group (4-methylumbelliferone) allowing fluorescence recording after reaction quenching at $\mathrm{pH} 10.7$ [64].
The BODIPY-based dye 13a displays an intense absorption at $528 \mathrm{~nm}\left(\varepsilon=27,000 \mathrm{M}^{-1} \cdot \mathrm{cm}^{-1}\right)$ corresponding to the $S_{0} \rightarrow S_{1}$ $\left(\pi-\pi^{*}\right.$ transition). The slight red shift of this absorption compared to unsubstituted BODIPY dyes in the 2,6-substitution positions and measured under similar aqueous conditions, is likely due to the influence of both triazole rings. The second transition at $386 \mathrm{~nm}$ is assigned in light of previous studies to the $S_{0} \rightarrow S_{2}$ of the BODIPY subunit [39,65-67]. The triazole rings absorb below $250 \mathrm{~nm}$ for the $\pi-\pi^{*}$ transition [68]. Excitation at $510 \mathrm{~nm}$ affords a relatively intense emission with a quantum yield of $24 \%$ (in aqueous glycine buffer at $\mathrm{pH} 10.7$ ), the profile of the band mirrors the absorption with a maximum 


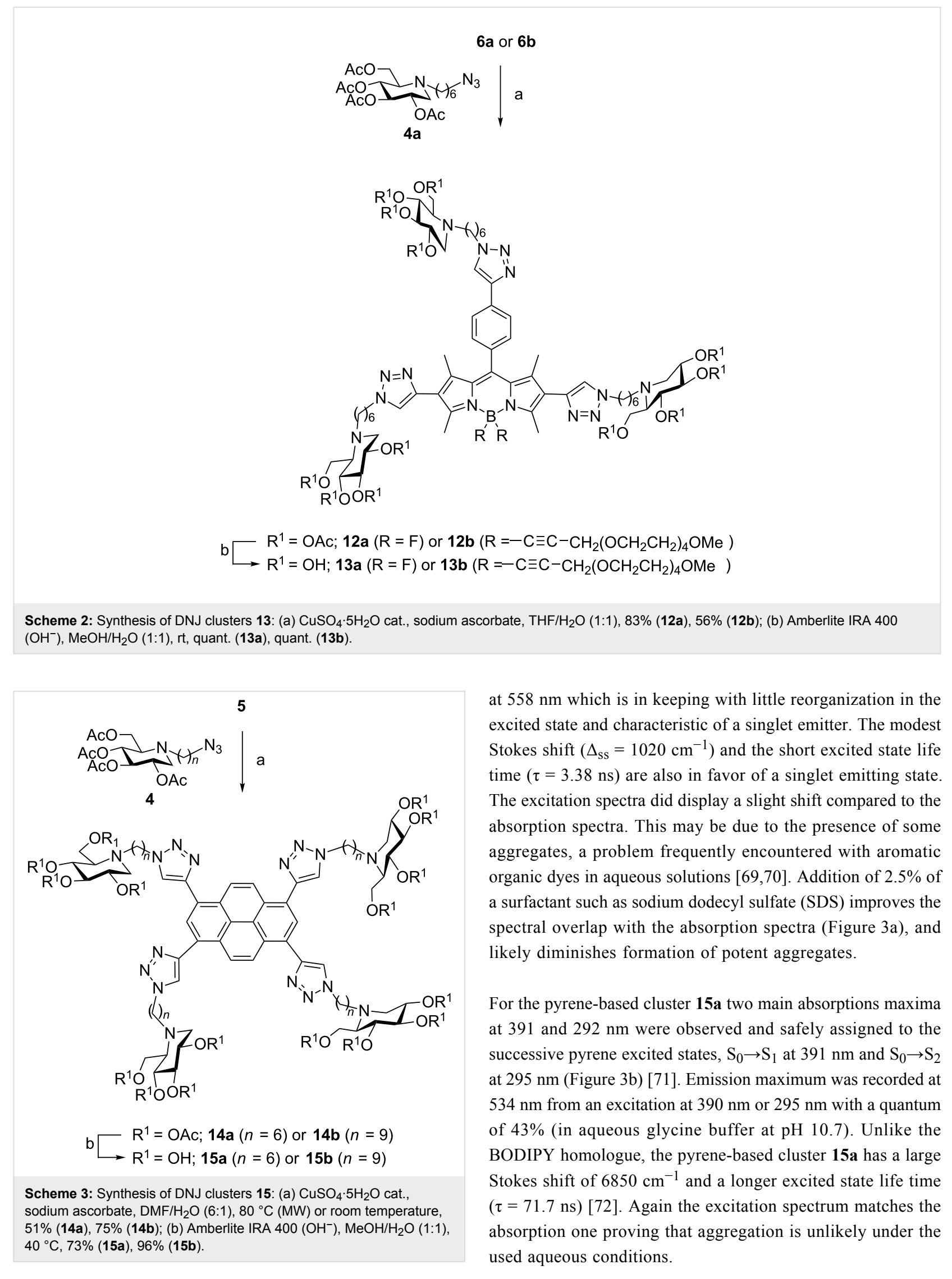




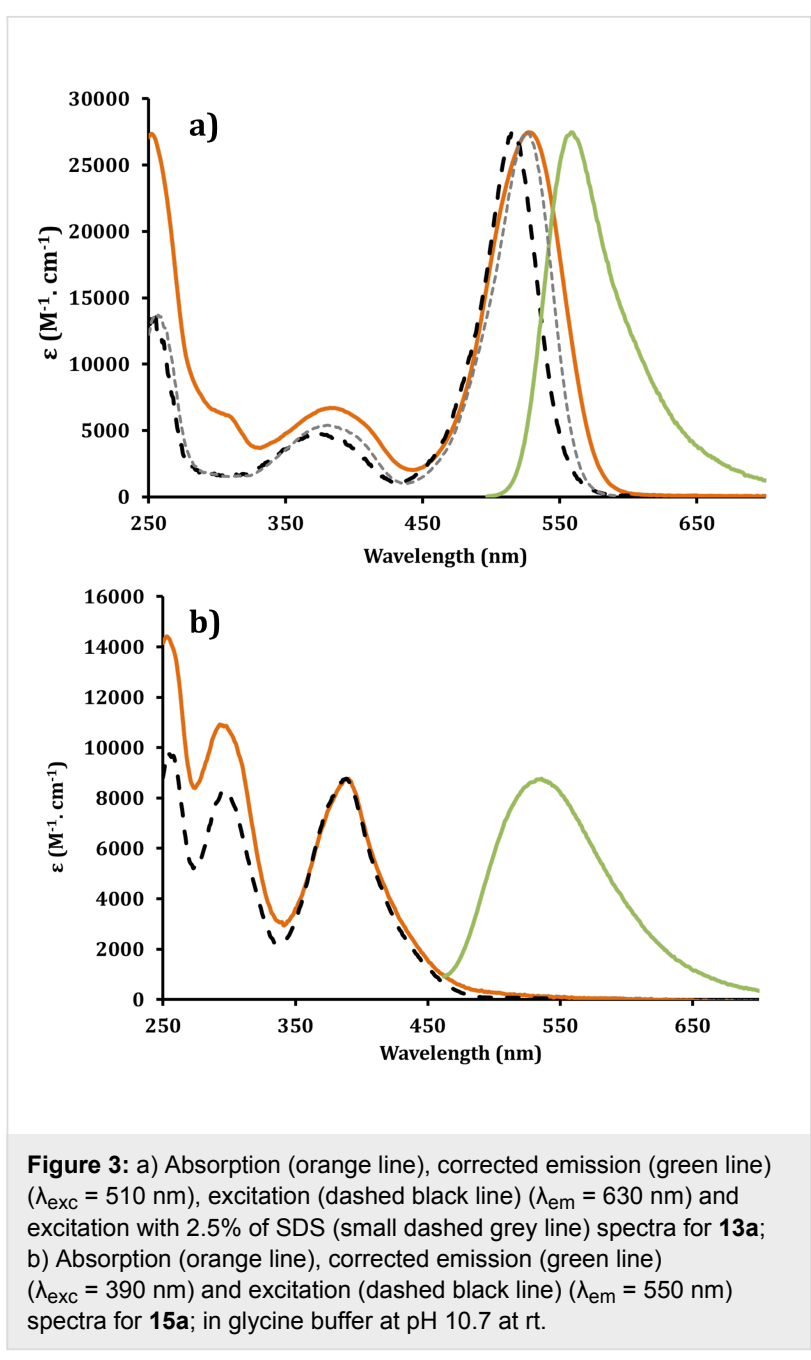

From a general point of view, fluorescent probes have been used for the detection of diverse analytes and in relevant biosensing and bioimaging applications [73]. One critical aspect for the evaluation of biological activities using fluorescent dyes (e.g., the deprotonated form of 4-methylumbelliferone) [74] is to determine their spectroscopic features in different environments (local $\mathrm{pH}$, local polarity, potential quenchers, hydrophobic environment, ...). Here we focus on the UV-visible characteristics of the anion of 4-methylumbelliferone, the dye commonly used for quantifying chaperoning activities (using 4-methylumbelliferyl $\beta$-D-glucopyranoside as GCase substrate) [64], to determine whether this assay would be compatible with the evaluation of fluorescent multivalent clusters $\mathbf{1 3}$ and $\mathbf{1 5}$ as potential pharmacological chaperones.

The same buffer conditions as those used for activation assays (quenched conditions at $\mathrm{pH} 10.7$ in a glycine buffer) were used for this study. The anion of 4-methylumbelliferone displays a strong absorption at $360 \mathrm{~nm}$ and a broad emission around $446 \mathrm{~nm}$ (Figure 4a).
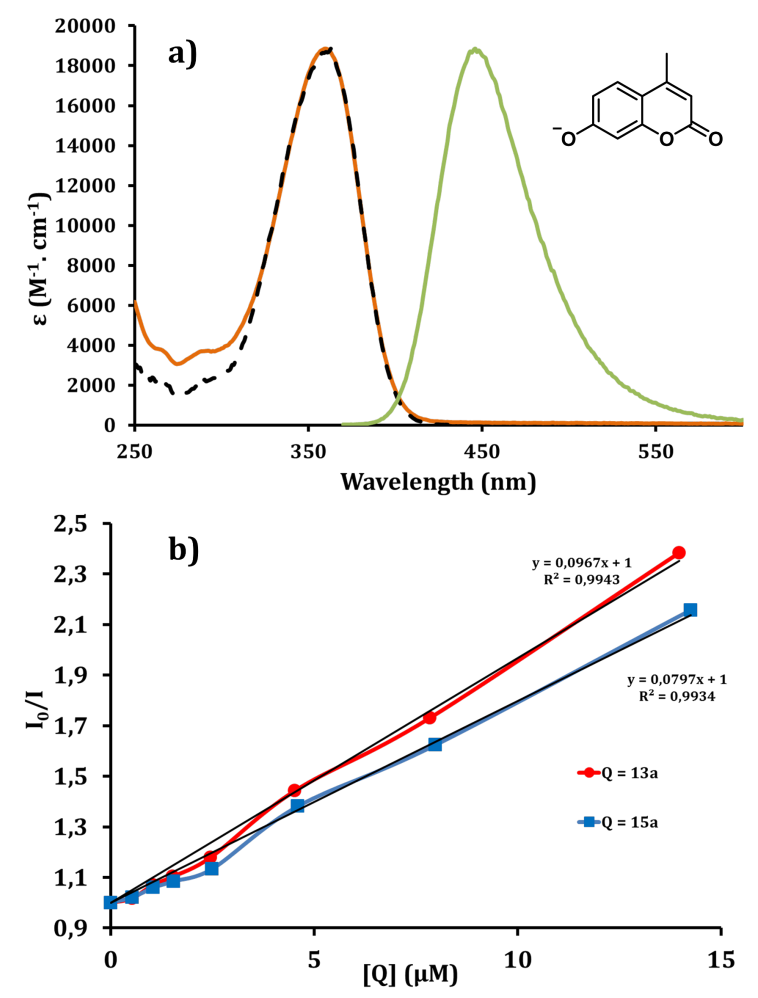

Figure 4: a) Absorption (orange line), corrected emission (green line) $\left(\lambda_{\text {exc }}=360 \mathrm{~nm}\right)$ and excitation (dashed black line) $\left(\lambda_{\mathrm{em}}=445 \mathrm{~nm}\right)$ spectra for the anion of 4-methylumbelliferone; b) Stern-Volmer plots concerning the quenching of fluorescence of the anion of 4-methylumbelliferone by $13 \mathrm{a}$ (red line) and $\mathbf{1 5 a}$ (blue line) and their linear regression.

The fluorescence quantum yield is high $\left(\phi_{\text {fluo }}=81 \%\right.$ ) as previously determined under similar conditions [74]. In order to record the efficiency of the fluorescence quenching of the anion of 4-methylumbelliferone by the novel dyes, Stern-Volmer plots were carried out [75]. A titrated solution of the quencher (13a or 15a) was dropwise added to a titrated solution of 4-methylumbelliferone $\left(\approx 10^{-7} \mathrm{M}\right.$ at $\left.\mathrm{pH} 10.7\right)$ and the fluorescence of the anion was recorded after each addition (Figure $4 \mathrm{~b}$ ). This allows plotting the decrease of fluorescence versus the concentration of quencher. The Stern-Volmer equation $I_{0} / I=1+k q \tau[Q]$ facilitates the calculation of the rates of bimolecular collisional quenching $k_{\mathrm{q}}=1.8 \times 10^{13} \mathrm{M}^{-1} \cdot \mathrm{s}^{-1}$ and $1.5 \times 10^{13} \mathrm{M}^{-1} \cdot \mathrm{s}^{-1}$, respectively for $\mathbf{1 3 a}$ and $\mathbf{1 5 a}$ dyes using a lifetime $\tau=5.31 \mathrm{~ns}$ for the 4-methylumbelliferone anion. The quenching appears efficient in both cases due to suitable spectral overlap between the emission of 4-methylumbelliferone anion and the absorption of the BODIPY 13a or the pyrenebased cluster 15a. This dynamic quenching process between these multivalent iminosugars and the 4-methylumbelliferone or other coumarine derivatives has thus to be taken into account 
during the quantitative analyses of dedicated biological processes.

\section{Conclusion}

We have reported the preparation of multivalent iminosugar clusters based on two fluorescent cores by way of $\mathrm{Cu}(\mathrm{I})$-catalysed azide-alkyne cycloadditions. To our knowledge these are the first examples of the use of BODIPY or pyrene as a scaffold to display multivalent ligands. Although the trivalent BODIPY-derived DNJ clusters are water soluble, a co-solvent is necessary to dissolve the tetravalent pyrene-derived DNJ clusters in water. Photophysical properties of those multivalent dyes in aqueous media (glycine buffer at $\mathrm{pH} 10.7$ ), are interesting, providing high quantum yields, $24 \%$ for 13 a and $43 \%$ for 15a, and well-defined spectroscopic features. Altogether, these results augur well for a new class of molecular tools dedicated to rationalize the mode of action of pharmacological chaperones and CFTR correctors by probing uptake and mapping biodistribution in cells and in vivo.

\section{Supporting Information}

\section{Supporting Information File 1}

Characterization data and NMR spectra of all new compounds.

[http://www.beilstein-journals.org/bjoc/content/ supplementary/1860-5397-11-74-S1.pdf]

\section{Acknowledgements}

This work was supported by the Institut Universitaire de France (IUF), the CNRS (UMR 7509), the University of Strasbourg, the Agence Nationale de la Recherche (ANR, grant number 11-BS07-003-02), the International Centre for Frontier Research in Chemistry (icFRC) and doctoral fellowships from the French Department of Research to Mathieu L. Lepage and Fabien Stauffert. Antoine Mirloup thanks the Rhin-Solar EC Network supported by the European Fund for Regional Development (FEDER) in the framework of the Programme INTERREG IV Upper Rhine, Project no. C25 for financial support of this work.

\section{References}

1. Iminosugars: from Synthesis to Therapeutic Applications; Compain, P.; Martin, O. R., Eds.; Wiley \& Sons: Chichester, United Kingdom, 2007. doi:10.1002/9780470517437

2. Stütz, A. E., Ed. Iminosugars as Glycosidase Inhibitors: Nojirimycin and Beyond; Wiley-VCH: New York, NY, U.S.A., 1999.

3. Moriyama, H.; Tsukida, T.; Inoue, Y.; Yokota, K.; Yoshino, K.; Kondo, H.; Miura, N.; Nishimura, S.-I. J. Med. Chem. 2004, 47, 1930-1938. doi:10.1021/jm0304313
4. Orsato, A.; Barbagallo, E.; Costa, B.; Olivieri, S.; De Gioia, L.; Nicotra, F.; La Ferla, B. Eur. J. Org. Chem. 2011, 5012-5019. doi:10.1002/ejoc.201100452

5. Decroocq, C.; Stauffert, F.; Pamlard, O.; Oulaïdi, F.; Gallienne, E.; Martin, O. R.; Guillou, C.; Compain, P. Bioorg. Med. Chem. Lett. 2015, 25, 830-833. doi:10.1016/j.bmcl.2014.12.071

6. Winchester, B. G. Tetrahedron: Asymmetry 2009, 20, 645-651. doi:10.1016/j.tetasy.2009.02.048

7. Horne, G.; Wilson, F. X. Prog. Med. Chem. 2011, 50, 135-176. doi:10.1016/B978-0-12-381290-2.00004-5

8. Nash, R. J.; Kato, A.; Yu, C.-Y.; Fleet, G. W. J. Future Med. Chem. 2011, 3, 1513-1521. doi:10.4155/fmc.11.117

9. Compain, P.; Bodlenner, A. ChemBioChem 2014, 15, 1239-1251. doi:10.1002/cbic.201402026

10. Gouin, S. G. Chem. - Eur. J. 2014, 20, 11616-11628. doi:10.1002/chem.201402537

11. Compain, P.; Decroocq, C.; lehl, J.; Holler, M.; Hazelard, D.; Mena Barragán, T.; Ortiz Mellet, C.; Nierengarten, J.-F. Angew. Chem., Int. Ed. 2010, 49, 5753-5756. doi:10.1002/anie.201002802

12. Decroocq, C.; Rodríguez-Lucena, D.; Russo, V.; Mena Barragán, T.; Ortiz Mellet, C.; Compain, P. Chem. - Eur. J. 2011, 17, 13825-13831. doi:10.1002/chem.201102266

13. Decroocq, C.; Joosten, A.; Sergent, R.; Mena Barragán, T.; Ortiz Mellet, C.; Compain, P. ChemBioChem 2013, 14, 2038-2049. doi:10.1002/cbic.201300283

14. Joosten, A.; Schneider, J. P.; Lepage, M. L.; Tarnus, C.; Bodlenner, A.; Compain, P. Eur. J. Org. Chem. 2014, 1866-1872. doi:10.1002/ejoc. 201301583

15. Bonduelle, C.; Huang, J.; Mena-Barragán, T.; Ortiz Mellet, C.; Decroocq, C.; Etamé, E.; Heise, A.; Compain, P.; Lecommandoux, S. Chem. Commun. 2014, 50, 3350-3352. doi:10.1039/c3cc48190e

16. Lepage, M. L.; Meli, A.; Bodlenner, A.; Tarnus, C.; De Riccardis, F.; Izzo, I.; Compain, P. Beilstein J. Org. Chem. 2014, 10, 1406-1412. doi:10.3762/bjoc. 10.144

17. Marradi, M.; Cicchi, S.; Sansone, F.; Casnati, A.; Goti, A. Beilstein J. Org. Chem. 2012, 8, 951-957. doi:10.3762/bjoc.8.107

18. Cardona, F.; Isoldi, G.; Sansone, F.; Casnati, A.; Goti, A. J. Org. Chem 2012, 77, 6980-6988. doi:10.1021/jo301155p

19. Brissonet, Y.; Ortiz Mellet, C.; Morandat, S.; Garcia Moreno, M. I.; Deniaud, D.; Matthews, S. E.; Vidal, S.; Šesták, S.; El Kirat, K.; Gouin, S. G. J. Am. Chem. Soc. 2013, 135, 18427-18435. doi:10.1021/ja406931w

20. Rísquez-Cuadro, R.; García Fernández, J. M.; Nierengarten, J.-F.; Ortiz Mellet, C. Chem. - Eur. J. 2013, 19, 16791-16803. doi:10.1002/chem.201303158

21. Moreno-Clavijo, E.; Carmona, A. T.; Moreno-Vargas, A. J.; Molina, L.; Wright, D. W.; Davies, G. J.; Robina, I. Eur. J. Org. Chem. 2013, 7328-7336. doi:10.1002/ejoc.201300878

22. D’Adamio, G.; Parmeggiani, C.; Goti, A.; Moreno-Vargas, A. J.; Moreno-Clavijo, E.; Robina, I.; Cardona, F. Org. Biomol. Chem. 2014, 12, 6250-6266. doi:10.1039/C4OB01117A

23. Marra, A.; Zelli, R.; D’Orazio, G.; La Ferla, B.; Dondoni, A. Tetrahedron 2014, 70, 9387-9393. doi:10.1016/j.tet.2014.10.035

24. Decroocq, C.; Rodríguez-Lucena, D.; Ikeda, K.; Asano, N.; Compain, P. ChemBioChem 2012, 13, 661-664. doi:10.1002/cbic.201200005

25. Joosten, A.; Decroocq, C.; de Sousa, J.; Schneider, J. P.; Etamé, E.; Bodlenner, A.; Butters, T. D.; Compain, P. ChemBioChem 2014, 15, 309-319. doi:10.1002/cbic.201300442 
26. Compain, P.; Decroocq, C.; Joosten, A.; de Sousa, J.; Rodríguez-Lucena, D.; Butters, T. D.; Bertrand, J.; Clément, R.; Boinot, C.; Becq, F.; Norez, C. ChemBioChem 2013, 14, 2050-2058. doi:10.1002/cbic. 201300312

27. Gavrin, L. K.; Denny, R. A.; Saiah, E. J. Med. Chem. 2012, 55 , 10823-10843. doi:10.1021/jm301182j

28. Gomes, C. M. Curr. Top. Med. Chem. 2012, 12, 2460-2469. doi:10.2174/1568026611212220002

29. Ribeiro-Viana, R.; García-Vallejo, J. J.; Collado, D.; Pérez-Inestrosa, E.; Bloem, K.; van Kooyk, Y.; Rojo, J. Biomacromolecules 2012, 13, 3209-3219. doi:10.1021/bm300998c See for examples of glycoclusters with a BODIPY tag and see ref. [30].

30. Hoogendoorn, S.; van Puijvelde, G. H. M.; Kuiper, J.; van derMarel, G. A.; Overkleeft, H. S. Angew. Chem., Int. Ed. 2014, 53, 10975-10978. doi:10.1002/anie.201406842

31. Ziessel, R.; Ulrich, G.; Harriman, A. New J. Chem. 2007, 31, 496-501. doi:10.1039/b617972j

32. Loudet, A.; Burgess, K. Chem. Rev. 2007, 107, 4891-4932. doi:10.1021/cr078381n

33. Ulrich, G.; Ziessel, R.; Harriman, A. Angew. Chem., Int. Ed. 2008, 47, 1184-1201. doi:10.1002/anie.200702070

34. Boens, N.; Leen, V.; Dehaen, W. Chem. Soc. Rev. 2012, 41 1130-1172. doi:10.1039/C1CS15132K

35. Willems, L. I.; Beenakker, T. J. M.; Murray, B.; Scheij, S.; Kallemeijn, W. W.; Boot, R. G.; Verhoek, M.; Donker-Koopman, W. E.; Ferraz, M. J.; van Rijssel, E. R.; Florea, B. I.; Codée, J. D. C.; van der Marel, G. A.; Aerts, J. M. F. G.; Overkleeft, H. S. J. Am. Chem. Soc. 2014, 136, 11622-11625.

36. Yadav, A. K.; Shen, D. L.; Shan, X.; He, X.; Kermode, A. R.; Vocadlo, D. J. J. Am. Chem. Soc. 2015, 137, 1181-1189. doi:10.1021/ja5106738

37. Davison, H. R.; Taylor, S.; Drake, C.; Phuan, P.-W.; Derichs, N.; Yao, C.; Jones, E. F.; Sutcliffe, J.; Verkman, A. S.; Kurth, M. J. Bioconjugate Chem. 2011, 22, 2593-2599. doi:10.1021/bc2004457

38. Haugland, R. P.; Kang, H. C. U.S. Patent 4,774,339, 1998.

39. Thoresen, L. H.; Kim, H.; Welch, M. B.; Burghart, A.; Burgess, K. Synlett 1998, 1276-1278. doi:10.1055/s-1998-1924

40. Goze, C.; Ulrich, G.; Charbonnière, L.; Ziessel, R. Chem. - Eur. J. 2003, 9, 3748-3755. doi:10.1002/chem.200305084

41. Qin, W.; Baruah, M.; Van der Auweraer, M.; De Schryver, F. C.; Boens, N. J. Phys. Chem. A 2005, 109, 7371-7384. doi:10.1021/jp052626n

42. Ulrich, G.; Goze, C.; Guardigli, M.; Roda, A.; Ziessel, R. Angew. Chem., Int. Ed. 2005, 44, 3694-3698. doi:10.1002/anie.200500808

43. Kim, H.; Burghart, A.; Welch, M. B.; Reibenspies, J.; Burgess, K. Chem. Commun. 1999, 1889-1890. doi:10.1039/a905739k

44. Chen, J.; Reibenspies, J.; Derecskei-Kovacs, A.; Burgess, K. Chem. Commun. 1999, 2501-2502. doi:10.1039/a907559c

45. Rurack, K.; Kollmannsberger, M.; Daub, J. New J. Chem. 2001, 25, 289-292. doi:10.1039/b007379m

46. Rurack, K.; Kollmannsberger, M.; Daub, J. Angew. Chem., Int. Ed. 2001, 40, 385-387. doi:10.1002/1521-3773(20010119)40:2<385::AID-ANIE385>3.0.CO;2$\mathrm{F}$

47. Ziessel, R.; Harriman, A. Chem. Commun. 2011, 47, 611-631. doi:10.1039/C0CC02687E

48. Ziessel, R.; Ulrich, G.; Haefele, A.; Harriman, A. J. Am. Chem. Soc. 2013, 135, 11330-11344. doi:10.1021/ja4049306
49. Turfan, B.; Akkaya, E. U. Org. Lett. 2002, 4, 2857-2859. doi:10.1021/ol026245t

50. Bricks, J. L.; Kovalchuk, A.; Trieflinger, C.; Nofz, M.; Büschel, M.; Tolmachev, A. I.; Daub, J.; Rurack, K. J. Am. Chem. Soc. 2005, 127, 13522-13529. doi:10.1021/ja050652t

51. Han, J.; Loudet, A.; Barhoumi, R.; Burghardt, R. C.; Burgess, K. J. Am. Chem. Soc. 2009, 131, 1642-1643. doi:10.1021/ja8073374

52. Hansen, J. S.; Ficker, M.; Petersen, J. F.; Christensen, J. B.; Hoeg-Jensen, T. Tetrahedron Lett. 2013, 54, 1849-1852. doi:10.1016/j.tetlet.2013.01.101

53. Bernhardt, S.; Kastler, M.; Enkelmann, V.; Baumgarten, M.; Müllen, K. Chem. - Eur. J. 2006, 12, 6117-6128. doi:10.1002/chem.200500999

54. Somerharju, P. Chem. Phys. Lipids 2002, 116, 57-74. doi:10.1016/S0009-3084(02)00020-8

55. Pownall, H. J.; Smith, L. C. Chem. Phys. Lipids 1989, 50, 191-211. doi:10.1016/0009-3084(89)90050-9

56. Leen, V.; Leemans, T.; Boens, N.; Dehaen, W. Eur. J. Org. Chem. 2011, 4386-4396. doi:10.1002/ejoc.201100324

57. Hornillos, V.; Amat-Guerri, F.; Acuña, A. U. J. Photochem. Photobiol., A: Chem. 2012, 243, 56-60. doi:10.1016/j.jphotochem.2012.06.005

58. Mula, S.; Ulrich, G.; Ziessel, R. Tetrahedron Lett. 2009, 50, 6383-6388. doi:10.1016/j.tetlet.2009.08.091

59. Bura, T.; Ziessel, R. Org. Lett. 2011, 13, 3072-3075. doi:10.1021/ol200969r

60. Bonardi, L.; Ulrich, G.; Ziessel, R. Org. Lett. 2008, 10, 2183-2186. doi:10.1021/ol800560b

61. Jahnke, E.; Weiss, J.; Neuhaus, S.; Hoheisel, T. N.; Frauenrath, H. Chem. - Eur. J. 2009, 15, 388-404. doi:10.1002/chem.200801668

62. Sonogashira, K.; Tohda, Y.; Hagihara, N. Tetrahedron Lett. 1975, 16 , 4467-4470. doi:10.1016/S0040-4039(00)91094-3

63. Isobe, H.; Fujino, T.; Yamazaki, N.; Guillot-Nieckowski, M.; Nakamura, E. Org. Lett. 2008, 10, 3729-3732. doi:10.1021/ol801230k

64. Valenzano, K. J.; Khanna, R.; Powe, A. C., Jr.; Boyd, R.; Lee, G.; Flanagan, J. J.; Benjamin, E. R. Assay Drug Dev. Technol. 2011, 9 , 213-235. doi:10.1089/adt.2011.0370

65. Chen, T.; Boyer, J. H.; Trudell, M. L. Heteroat. Chem. 1997, 8, 51-54. doi:10.1002/(SICI)1098-1071(1997)8:1<51::AID-HC7>3.0.CO;2-5

66. Sathyamoorthi, G.; Wolford, L. T.; Haag, A. M.; Boyer, J. H. Heteroat. Chem. 1994, 5, 245-249. doi:10.1002/hc.520050309

67. Burghart, A.; Kim, H.; Wech, M. B.; Thoresen, L. H.; Reibenspies, J.; Burgess, K. J. Org. Chem. 1999, 64, 7813-7819. doi:10.1021/jo990796o

68. Potts, K. T. Chem. Rev. 1961, 61, 87-127. doi:10.1021/cr60210a001

69. Niu, S.-L.; Ulrich, G.; Retailleau, P.; Harrowfield, J.; Ziessel, R. Tetrahedron Lett. 2009, 50, 3840-3844. doi:10.1016/j.tetlet.2009.04.017

70. Niu, S. L.; Ulrich, G.; Ziessel, R.; Kiss, A.; Renard, P.-Y.; Romieu, A. Org. Lett. 2009, 11, 2049-2052. doi:10.1021/ol900302n

71. Berlman, I. B. Handbook of Fluorescence Spectra of Aromatic Molecules; Academic Press: New York, NY, USA, 1971.

72. Geiger, M. W.; Turro, N. J. Photochem. Photobiol. 1975, 22, 273. doi:10.1111/j.1751-1097.1975.tb06749.x

73. Kaur, M.; Choi, D. H. Chem. Soc. Rev. 2015, 44, 58-77. doi:10.1039/C4CS00248B

74. Chen, R. F. Anal. Lett. 1968, 1, 423-428. doi:10.1080/00032716808051147

75. Stern, O.; Volmer, M. Phys. Z. 1919, 20, 183-188. 


\section{License and Terms}

This is an Open Access article under the terms of the Creative Commons Attribution License

(http://creativecommons.org/licenses/by/2.0), which permits unrestricted use, distribution, and reproduction in any medium, provided the original work is properly cited.

The license is subject to the Beilstein Journal of Organic Chemistry terms and conditions:

(http://www.beilstein-journals.org/bjoc)

The definitive version of this article is the electronic one which can be found at:

doi:10.3762/bjoc. 11.74 